Scientia Marina 70 (2)

June 2006, 177-188, Barcelona (Spain)

ISSN: 0214-8358

\title{
Vertical distribution and trophic structure of the macrozooplankton in a shallow temperate estuary (Ria de Aveiro, Portugal)
}

\author{
FERNANDO M. MORGADO ${ }^{1}$, M. RAMIRO PASTORINHO ${ }^{1}$, \\ CARLA QUINTANEIRO ${ }^{1}$ and PEDRO RÉ ${ }^{2}$ \\ ${ }^{1}$ Departamento de Biologia, Universidade de Aveiro, Campus de Santiago, 3810-193 Aveiro, Portugal. \\ E-mail: fmorgado@bio.ua.pt \\ ${ }^{2}$ Departamento de Biologia Animal. Faculdade de Ciências da Universidade de Lisboa. 1749-016 Lisboa, Portugal.
}

SUMARY: The zooplankton of the lower part of Canal de Mira (Ria de Aveiro) was sampled during one lunar month. The sampling programme consisted of nine 25 hour fixed-cycles, separated weekly. In each cycle, samples were collected every two hours at three depths (surface, mid-water and above the bottom) with a $500 \mu \mathrm{m}$ mesh net. The overall effect of the tidal phase was analyzed, taking into account the day and depth of the vertical position of the organisms through a 3-way analysis of variance (ANOVA). The zooplankton densities were, in general, higher at the surface during the night and near the bottom during the day, mainly at spring tide. The variation in the number of species followed a similar pattern to that observed for abundance. Significant differences $(\mathrm{p}<0.01)$ between diel and tidal phases were observed. Interaction between phase of the day and depth was also significant $(\mathrm{p}<0.05)$, with higher organism densities observed during night periods near the bottom. From a trophic point of view the zooplankton community of Canal de Mira was mainly composed of carnivorous and omnivorous species. Carnivores were significantly more abundant around the new and full moon $(p<0.001)$, the omnivores at the new moon $(\mathrm{p}<0.001)$ and the herbivores and detritivores at the first quarter of the moon cycles $(\mathrm{p}<0.001)$. The density of carnivores was significantly higher at the surface at night and near the bottom during the day $(\mathrm{p}<0.05)$. Significant differences in the abundance of omnivores were observed between phases of the day and between depths, with higher values near the bottom during the day. The herbivores and detritivores had significantly higher densities during flood tides $(\mathrm{p}<0.001)$

Keywords: macrozooplankton, vertical distribution, trophic structure, temperate estuary.

RESUMEN: DisTIBUICIÓN VERTICAL Y ESTRUCTURA TRÓFICA DEL MACROZOOPLANCTON EN UN ESTUARIO TEMPLADO (RIA DE AvEIRo). - El zooplancton de la parte inferior del Canal de Mira (Ria de Aveiro) fue muestreado durante un mes lunar. El programa de muestreo consistió en nueve ciclos de 25 horas, con periodicidad semanal. En cada ciclo, las muestras fueron recogidas cada dos horas, a tres profundidades (superficie, columna de agua y sobre el fondo) con una red de $500 \mu \mathrm{m}$. El efecto total de la fase de la marea fue analizado, teniendo en consideración el día y la profundidad en la posición vertical de los organismos con un análisis 3-Way ANOVA. Las densidades del zooplancton fueron en general más altas en la superficie durante la noche y cercanas al fondo durante el día, principalmente em la marea viva. La variación en el número de especies siguió un patrón similar al observado para la abundancia. Se observaron diferencias significativas $(\mathrm{p}<0.01)$ entre las fases del día y las fases de marea. La interacción entre la fase del día y la profundidad fue también significativa $(\mathrm{p}<0.05)$ con densidades de organismos más altas durante los periodos nocturnos en el fondo. De un punto de vista trófico, la comunidad zooplanctónica del Canal de Mira está principalmente compuesta por especies carnívoras y omnívoras. Los carnívoros fueram significativamente más abundantes cerca de la luna nueva y de la luna llena $(p<0.001)$, los omnívoros en la luna nueva $(\mathrm{p}<0.001)$ y los herbívoros e detritívoros en el primero cuarto de los ciclos de la luna $(\mathrm{p}<0.001)$. La densidad de los carnívoros fue significativamente más alta en la superficie durante la noche y en el fondo durante el día ( $\mathrm{p}<0.05)$. Para los omnívoros, fueron observadas diferencias significativas entre las fases del día y la profundidad, registando valores más elevados en el fondo durante el día. Los herbívoros y los detritívoros presentaron densidades significativamente superiores durante los ciclos de marea $(\mathrm{p}<0.001)$.

Palabras clave: macrozooplancton, distribución vertical, estructura trófica, estuario templado. 


\section{INTRODUCTION}

Vertical distribution patterns of zooplankton are complex phenomena involving several categories of behaviours that change from species to species, and even from individual to individual, and depend on factors such as endogenous rhythms, age, sex and spawning (Wooldrige and Erasmus, 1980; Hammer, 1981; Orsi, 1986; Saint-Jean and Pagano, 1990; Stuart and Verheye, 1991; Hays, 2003). Vertical migrations of zooplankton are nearly ubiquitous in both freshwater and marine systems and thus are well documented in the literature (Enright, 1970; Schwassmann, 1971; Decoursey, 1983; Lampert, 1989; Neilson and Perry, 1990; Hays, 2003). External factors such as light intensity, season, lunar phase and tidal cycles, temperature and salinity may affect migratory behaviour (Hammer, 1981; Paffenhoper, 1983; Gajbhiye et al., 1984; Magnesen, 1989; Magnesen et al., 1989; Fragopoulu and Lykakis, 1990). Many evolutionary hypotheses have been developed to explain the mechanisms behind zooplankton vertical migrations. Predator evasion (Zaret and Suffern, 1976; Gliwicz, 1986; Harding et al., 1986; Simard et al., 1986; Dodson, 1988; Bollens and Frost, 1989a,b; Giske et al., 1990; Neill, 1990; Stuart and Verheye, 1991; Yamaguchi et al., 2004) and longitudinal transport control (Brookins and Epifanio, 1985; Epifanio, 1988; Hill, 1991a,b,c, 1995) are currently the most favoured hypotheses. Enright (1977) also suggested that vertical migration provides metabolic advantages.

Vertical migrations interact with horizontal currents and vary with depth, and so the extension and direction of horizontal transport may be modified by depth change of the organisms' distribution. The zooplankton community structure is mainly a result of physical constraints and trophic factors at both higher and lower levels. The zooplankton community is itself a main regulating factor for these trophic levels, making the pelagic system a dynamic system, where trophic interactions are seldom in equilibrium (Hansson et al., 1990). Within the context of a broad trophic network that varies in time and space, the interactions of producers and consumers have profound consequences for aquatic ecosystems giving rise, for instance, to large regional and seasonal variations in the magnitudes of phytoplankton standing stocks (blooms), nutrient utilization and recycling efficiencies and export ratios (Marine Zooplankton
Colloquium, 2001). Consequently, changes in zooplankton communities may lead to changes in the trophic structure and functioning of aquatic ecosystems. The extent to which zooplankton responds to different environmental cues is not well understood, in particular, it is not known how much of zooplankton behaviour is in response to the surrounding physical environment. There may also be an endogenous rhythm cuing the migration (Neumann, 1981; Forward, 1988), and other internal factors, such as nutritional status or accumulated energy, may play a role (Sekino and Yamamura, 1999). Daynight cycles are also reliable cues for their activities. Hence, estuarine organisms show activity patterns that are synchronized with both day-night and tidal cycles (Saigusa, 1985; Saigusa and Akiyama, 1995).

Analysis of feeding habits may provide essential information for understanding zooplankton dynamics and defining the type of aquatic structure. This would contribute to interpreting the mechanisms underlying adaptation of the species to estuarine circulation (Laprise and Dodson, 1993) and to a deeper knowledge of the functional aspects of the pelagic system as a whole (Magnesen, 1989; Magnesen et al., 1989). A previous study analyzed species composition, function and patterns of emergence inside and in the coastal vicinity of the studied system (see Morgado et al., 2003a,b). The objective of this paper is to describe the trophic structure dynamic interactions of the zooplanktonic compartment as a coherent assemblage.

In order to fulfil these objectives, field sampling was designed to reveal a set of variables, namely: i) the vertical distribution profiles in the water column for a complete lunar month; ii) the effects of the phases of the day, tide and moon on behaviour and species abundance; iii) the distribution patterns and the nictemeral, tidal and lunar trophic structures.

\section{MATERIALS AND METHODS}

\section{Study site}

Ria de Aveiro is a shallow bar-built estuary (Dias et al., 2003) on the northwest Portuguese coast with a wet area of $47 \mathrm{~km}^{2}$ at high tide and $42 \mathrm{~km}^{2}$ at low tide, with a maximum length and width of $40 \mathrm{~km}$ and $10 \mathrm{~km}$ respectively. The lagoon has a rather complex topography, comprising an extensive reticulate of channels radiating from the contact with the 


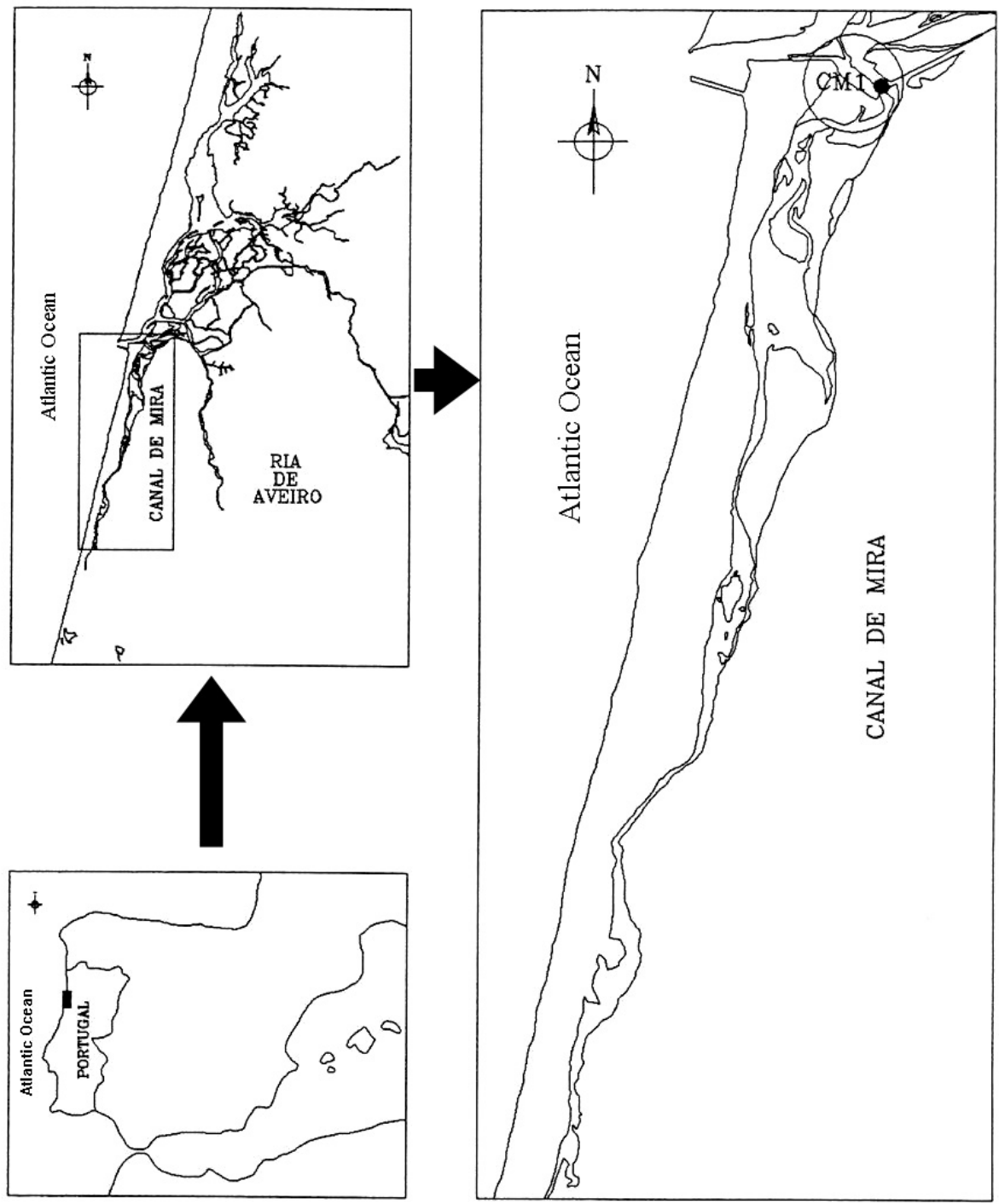

FIG. 1. - Canal de Mira, Ria de Aveiro, Portugal. Location of station used during the fixed station studies.

Atlantic (Fig. 1). Tidal influence is the main factor influencing circulation within the estuary. The volume of seawater entering the estuary on each flood is $25 \times 10^{6} \mathrm{~m}^{3}$ (1 $\mathrm{m}$ tidal range), reaching up to $96 \times 10^{6} \mathrm{~m}^{3}$ if the $3 \mathrm{~m}$ level is reached. The sum of all fresh water entering this water body (in the same period of time) only amounts to $2 \times 10^{6} \mathrm{~m}^{3}$. The tidal regime is semi-diurnal with an average tidal range of $2.1 \mathrm{~m}$ at the inlet (Dias et al., 2003).

The study site was located in the Canal de Mira (which functions as a mesotidal estuary in itself) (Fig. 1) which evolves from the inlet towards the southeast, parallel to the coastline, with an approximate extension of $20 \mathrm{~km}$ and a maximum width of 1 $\mathrm{km}$. It has a maximum depth of $9 \mathrm{~m}$ below mean sea level near the mouth and is seldom below 0.5 in its final $2 / 3$. Freshwater flows in continuously from a system of creeks and lagoons. The average discharge is $7.8 \mathrm{~m}^{3} \mathrm{~s}^{-1}$. This channel is characterized by a positive longitudinal salinity gradient influenced by tides and seasonal cycles. The residual circulation is a two-layer flow with vertical mixing.

\section{Field sampling}

In this study, nine $25 \mathrm{~h}$ plankton sampling cycles were performed at station \#1, at weekly intervals. The mean depth of the sampling station was $6.5 \mathrm{~m}$. The tidal range was $2.3 \mathrm{~m}$ throughout the study. Mean differences between bottom and surface flood current inversions did not exceed 4 minutes. However, the ebb slack had an average displacement of about 16 to 18 minutes between the surface and bottom. 
The samples were taken along the deepest zone of the channel, every two hours, with a tow velocity of 1 to $2 \mathrm{~ms}^{-2}$, against the water flow, for 5 minutes, using three $500 \mu \mathrm{m}$ mesh size nets (neustonic, midwater and epibenthic (Queiroga, 1995) deployed in quick succession, each of them equipped with a flowmeter. The neustonic net, with an opening of $0.60 \times 0.30 \mathrm{~m}$, was deployed so that the immersed part would be, on average, $20 \mathrm{~cm}$ deep. The midwater net, of conic shape with a $0.40 \mathrm{~m}$ diameter opening, was towed through a frame hinged to the mouth of the net, with a $10 \mathrm{~kg}$ ballast. Tows were made taking the precaution that the towing cable never exceeded an angle $>50^{\circ}$. Simultaneously this allowed extra precision in regulating towing depth. The epibenthic net, similar to the one used for midwater hauls, was mounted on a sledge, which allowed a regular $0.30 \mathrm{~m}$ distance between the centre of the net opening and the bottom to be maintained. Despite the absence of a net opening-closing device the calculated overall interference was never bigger than $5 \%$ of the total filtered volume. Average filtered water volumes were $35.1,30.7$ and $25.3 \mathrm{~m}^{-3}$ for the neuston, mid-water and epibenthic nets respectively.

Samples were fixed and preserved in 5\% buffered formaldehyde. Sub-sampling was made using a Folsom plankton splitter (McEwen et al., 1954), counting a fraction of 100 individuals for the most abundant taxa, and at least 500 individuals per sample. The abundance of taxa was expressed as number of individuals per cubic meter.

Classifying planktonic species into herbivorous, carnivorous, detritivorous and omnivorous is a sensitive matter since, despite some species possessing relatively fixed feeding habits, the great majority are very flexible, and are capable of modifying their feeding behaviour according to the availability and/or the quality of food resources. Bearing this in mind, the presiding classification criterion was to place each species into the corresponding predominant feeding regime as determined by the structure of their mouthpieces; we considered herbivores+detritivorous, post-veligers Hydrobia ulvae and Oikopleura dioica; omnivorous Acartia clausi, Gastrosaccus spinifer, Schistomysis spiritus, Gastrosaccus spinifer juvenils and Schistomysis spiritus juvenils; carnivorous Obelia spp., Dipurena ophiogaster, Muggiaea atlantica, Diphyes spp., metatrocophores Lanice conchilega, Calanus helgolandicus, zoeae Palaemon elegans, zoeae
Crangon crangon, post-larvae Crangon crangon, zoeae Carcinus maenas and zoeae Pachygrapsus marmoratus (Rose, 1933; Russell, 1953; Tregóbouff and Rose, 1957; Totton and Bargmann, 1965; Fenaux, 1967; Rice and Ingle, 1975a,b; Fincham, 1977; Maucline in Blaxter et al., 1980; Guerney, 1982; Fincham and Figueras, 1986; Ingle, 1987; Barnes, 1994).

\section{Statistical analysis}

The overall effect of the tide phase was analyzed, taking into account the time of day and depth through a 3-way analysis of variance (ANOVA). All samples collected during each sampling moment were considered replicates. They were classified as ebb or flood samples according to the phase of the tide, defined by high and low water slack times, during which the discrete time interval began. Similarly, the samples were classified as day or night, where the day was taken as the period between sunrise and sunset and the night as the balance of this period. The three sampling depths (surface, mid-water and bottom) constituted the levels for this factor. Prior to analysis, data were subjected to a $\log (x+1)$ transformation in order to achieve parametric analysis requirements (Zar, 1984).

\section{RESULTS}

\section{Zooplankton density}

The most abundant groups were the pelagic and the suprabenthic crustaceans, especially Decapoda larvae, Copepoda and Mysidacea, but also Mollusca larvae, Siphonophora, Hydromedusae, Polychaeta larvae and Appendicularia (Table 1). The dominant species were the zoeae of Carcinus maenas, eggs of Littorina littorea, Acartia clausi, Gastrosaccus spinifer and Diphyes spp., which represented $57 \%$ of the zooplankton community. However, species such as Obelia spp., Dipurena ophiogaster, Muggiaea atlantica, unidentified nectophores and gonophores, metatrocophores of Lanice conchilega, post-veligers of Hydrobia ulvae, Calanus helgolandicus, Temora longicornis, Schistomysis spiritus, zoeae of Palaemon elegans, zoeae of Crangon crangon, postlarvae of Crangon crangon, zoeae of Pachygrapsus marmoratus and Oikopleura dioica collectively represented $32 \%$ of the total zooplankton. 
TABLE 1. - Taxonomical groups and most representative species, per group, identified in the samples. Average concentration (ind. $\mathrm{m}^{-3}$ ) and percentage contribution to the mean total density.

\begin{tabular}{|c|c|c|c|}
\hline Taxonomic Groups & & Mean density (ind $\mathrm{m}^{-3}$ ) & Percentage $(\%)$ \\
\hline Hydromedusae & $\begin{array}{l}\text { Obelia spp. } \\
\text { Dipurena ophiogaster }\end{array}$ & $\begin{array}{l}1 \\
1\end{array}$ & $\begin{array}{l}1 \\
1\end{array}$ \\
\hline Siphonophora & $\begin{array}{l}\text { Muggiaea atlantica } \\
\text { Dyphies spp. }\end{array}$ & $\begin{array}{l}1 \\
5\end{array}$ & $\begin{array}{c}1.4 \\
6\end{array}$ \\
\hline Polychaeta larvae & Metatrocophores L. conchilega & 3 & 4.3 \\
\hline Mollusca larva /eggs & $\begin{array}{l}\text { Post-veligers Hydrobia ulvae } \\
\text { Littorina littorea eggs }\end{array}$ & $\begin{array}{c}1 \\
11\end{array}$ & $\begin{array}{c}0.7 \\
13.6\end{array}$ \\
\hline Copepoda & $\begin{array}{l}\text { Calanus helgolandicus } \\
\text { Acartia clausi }\end{array}$ & $\begin{array}{c}1 \\
10\end{array}$ & $\begin{array}{l}1.2 \\
12.5\end{array}$ \\
\hline Mysidacea & $\begin{array}{l}\text { Juvenils Gastrosaccus spinifer } \\
\text { Adults Gastrosaccus spinifer } \\
\text { Juvenils Schistomysis spiritus } \\
\text { Adults Schistomysis spiritus }\end{array}$ & $\begin{array}{l}1 \\
8 \\
1 \\
2\end{array}$ & $\begin{array}{l}1.6 \\
9.6 \\
1.3 \\
2.4\end{array}$ \\
\hline Decapoda larvae & $\begin{array}{l}\text { Zoeae Palaemon elegans } \\
\text { Zoeae Carcinus maenas } \\
\text { Zoeae Crangon crangon } \\
\text { Post-larvae Crangon crangon }\end{array}$ & $\begin{array}{c}0.4 \\
12 \\
3 \\
0.4\end{array}$ & $\begin{array}{c}0.5 \\
15.6 \\
4 \\
0.5\end{array}$ \\
\hline Appendicularia & Oikopleura dioica & 3 & 4.3 \\
\hline Other & & & 18.5 \\
\hline
\end{tabular}
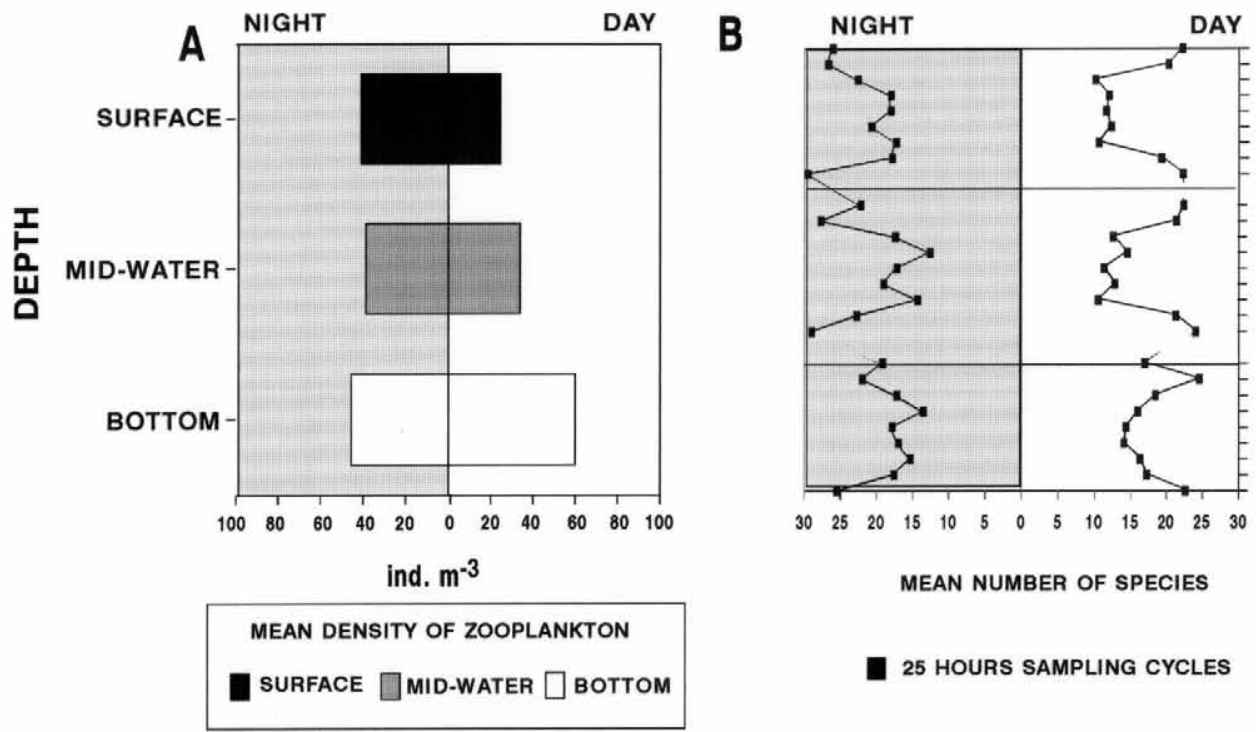

FIG. 2. - Mean density of zooplankton (A) and mean number of species (B), at the three depths, in the day and night periods. Concentrations (ind. $\mathrm{m}^{-3}$ ) are represented by horizontal bars. Shaded area: night.

The analysis of variation of the zooplankton mean density as a function of depth and phase of the day, suggests that densities were higher near the bottom during both the day and night. Mean surface density during the night (41 ind. $\mathrm{m}^{-3}$ ) was approximately half of that recorded during the day $\left(25\right.$ ind. $\left.\mathrm{m}^{-3}\right)$. Near the bottom, high densities were observed both during the day $\left(60\right.$ ind. $\left.\mathrm{m}^{-3}\right)$ and at night (46 ind. $\mathrm{m}^{-3}$ ). The mean number of species was higher at the surface and mid-water, and during the day near the bottom (Fig. 2).

The analysis of the zooplankton mean density as a function of the phase of the tide and depth, suggests higher values during floods rather than during 


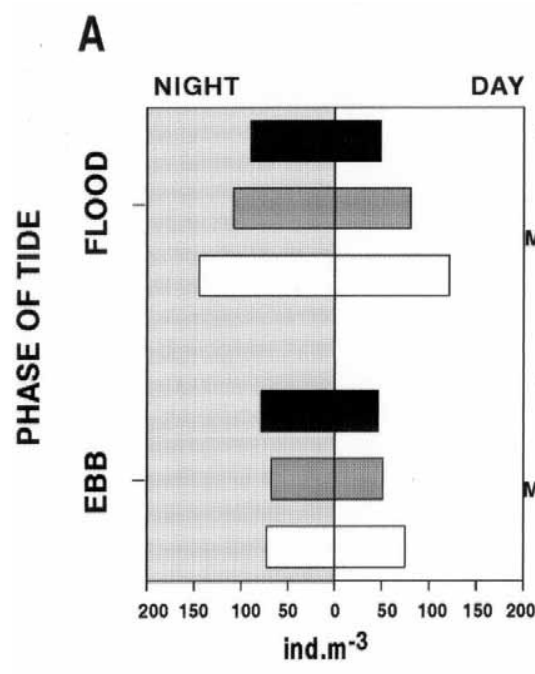

MEAN DENSITY OF ZOOPLANKTON

SURFACE
B

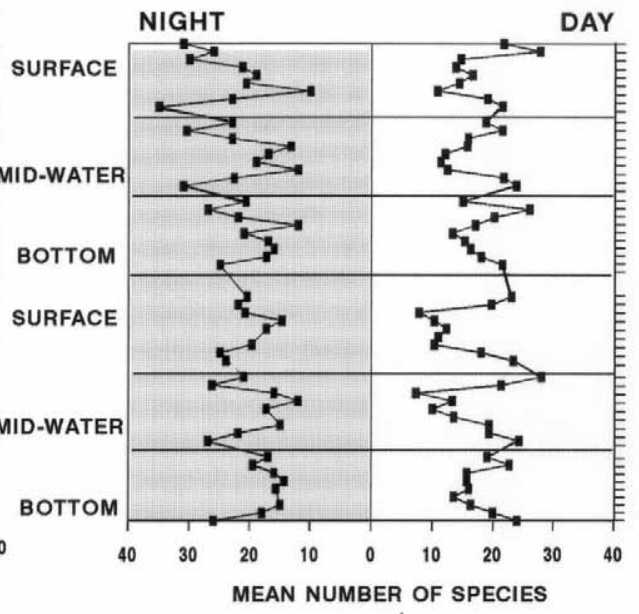

25 HOURS SAMPLING CYCLES

FIG. 3. - Mean density of zooplankton (A) and mean number of species (B), during flood and ebbs, in the day and night periods, at the three depths. Concentrations (ind. $\mathrm{m}^{-3}$ ) are represented by horizontal bars. Shaded area: night.

ebbs. It also shows that during floods, both diurnal and nocturnal densities were higher in mid-water and near the bottom. For ebbs, the pattern was of higher densities at the surface during the night and near the bottom during the day. Generally, differences in concentrations were a lot higher during floods compared with ebbs (Fig. 3).

The analysis of the zooplankton mean density in the four moon phases as a function of the time of the day and depth, suggests that values were markedly higher during the new moon, both during the day

A

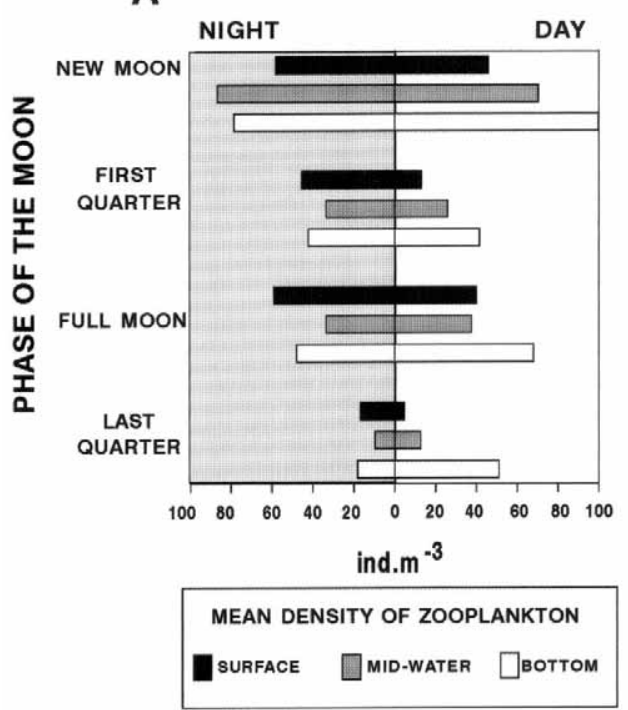

and night, with a maximum value of 100 ind. $\mathrm{m}^{-3}$ near the bottom during the day. During the full moon and first quarter phases, striking differences with depth were observed only during the day. The highest mean densities were observed during full moon periods near the bottom during the day $\left(68\right.$ ind. $\left.\mathrm{m}^{-3}\right)$ and at the surface during the night (59 ind. $\left.\mathrm{m}^{-3}\right)$, as well as during the first quarter in the daytime near the bottom (42 ind. $\mathrm{m}^{-3}$ ) and at night at the surface (45 ind. $\mathrm{m}^{-3}$ ). In the second quarter, densities were low, especially at the surface and in mid-water, both

B

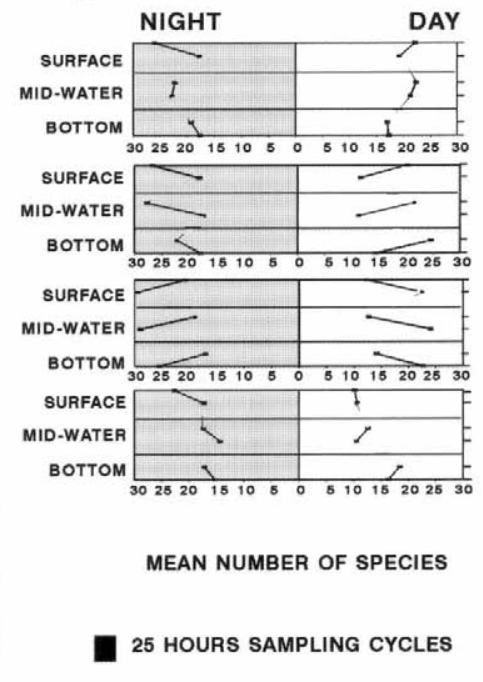

FIG. 4. - Mean density of zooplankton (A) and mean number of species (B), during the phases of the moon, in the day and night periods, at the three depths. Concentrations (ind. $\mathrm{m}^{-3}$ ) are represented by horizontal bars. Shaded area: night. 
TABLE 2. - Results of the 3-way ANOVAs of the effects of phase of tide, time of day, depth level and interactions, on the zooplankton concentration, the mean number of species and on the zooplankton trophic level concentrations; ns=not significant; $*=\mathrm{p}<0.05 ; * *=\mathrm{p}<0.01 ; * * *=\mathrm{p}<0.001$.

\begin{tabular}{|c|c|c|c|c|c|}
\hline & MS & Fs & $\mathrm{P}$ & & \\
\hline \multicolumn{6}{|l|}{ Zooplankton concentration } \\
\hline Phase of the day & & 6.096 & 20.800 & 0.001 & $* * *$ \\
\hline Depth & & 3.223 & 10.997 & 0.001 & $* * *$ \\
\hline \multicolumn{6}{|l|}{ Mean number of species } \\
\hline $\begin{array}{l}\text { Phase of the day } \\
\text { Phe }\end{array}$ & & 0.895 & 18.972 & 0.001 & $* * *$ \\
\hline Phase of the tide & & 0.183 & 3.884 & 0.050 & * \\
\hline Phase of the day by depth & & 0.289 & 6.114 & 0.002 & $* *$ \\
\hline \multicolumn{6}{|l|}{ Zooplankton trophic levels concentration } \\
\hline Phase of the day & Omnivorous & 16.151 & 53.006 & 0.001 & $* * *$ \\
\hline Phase of the tide & Herbivorous + Detritivorous & 1.164 & 6.179 & 0.013 & $*$ \\
\hline Depth & Omnivorous & 12.484 & 40.969 & 0.001 & $* * *$ \\
\hline \multirow[t]{3}{*}{ Phase of the moon } & Herbivorous + Detritivorous & 3.684 & 22.630 & 0.001 & $* * *$ \\
\hline & Omnivorous & 4.653 & 18.377 & 0.001 & $* * *$ \\
\hline & Carnivorous & 1.162 & 3.466 & 0.017 & $* *$ \\
\hline Phase of the day vs. Depth & Carnivorous & 1.280 & 3.727 & 0.025 & $*$ \\
\hline Phase of the moon vs. Phase of the day & Omnivorous & 1.054 & 4.162 & 0.007 & $* *$ \\
\hline
\end{tabular}

during the day and the night. Nevertheless, the density during this phase of the moon near the bottom and during the day (51 ind. $\mathrm{m}^{-3}$ ) was of equivalent magnitude to the densities observed during the full moon and the first quarter phases (Fig. 4). The mean number of species was especially higher during the day in full moon phases. In the second quarter and new moon phases during the night an identical number of species was observed. Nevertheless during the day in the latter phase the number of species was markedly lower (Fig. 4).

In order to test the significance of the observed differences in zooplankton density and in the number of species as a function of day and tide phases, depth and the overall effect resulting from the interaction of all factors, an analysis of variance was performed (ANOVA). In terms of density, only differences between the phases of the day $(\mathrm{p}<0.001)$ and sampling depths were significant $(\mathrm{p}<0.001)$ (Table 2 ). The significant differences in terms of the number of species, were between the phases of the day $(p<0.001)$ and phases of the tide $(p<0.05)$, as well as for the interaction between the phases of the day and depths $(\mathrm{p}<0.01)$ (Table 2).

\section{Distribution of taxa by trophic level}

In the Mira channel, zooplankton communities were mainly composed of carnivores and omni- vores, representing 42 and $30 \%$ of the total zooplankton respectively. Herbivores represented only $5 \%$ of the entire community. Carnivores were significantly more abundant at the surface during the night and at the bottom during the day in new moon and full moon cycles $(\mathrm{p}<0.01)$ (Figs. 5, 7). This interaction between depth and phase of the day was also observed for omnivores, which were more abundant during the night near the bottom in new moon cycles $(\mathrm{p}<0.01)$. Herbivores and detritivores exhibited significantly higher densities during floods, especially during the first quarter (Figs. 6, 7).

Analysis of the mean density of the different trophic levels as a function of the phases of the day and depths shows that both carnivores and omnivores were considerably more abundant than herbivores and detritivores. Carnivores always constituted more than $33 \%$ of the total zooplankton in both phases of the day at any depth; they exhibited the highest concentrations during the night at the surface and during the day near the bottom (Fig. 5). A significant interaction $(\mathrm{p}<0.05)$ was found between the phases of the day and depths (Table 2). Carnivores exhibited a mean density of 78 ind. $\mathrm{m}^{-3}$ at the surface during the night (representing, in this context, $80 \%$ of the total zooplankton) and 46 ind. $\mathrm{m}^{-3}$ near the bottom during the day (representing $52 \%$ of the total). Omnivores followed a similar pattern, with signif- 


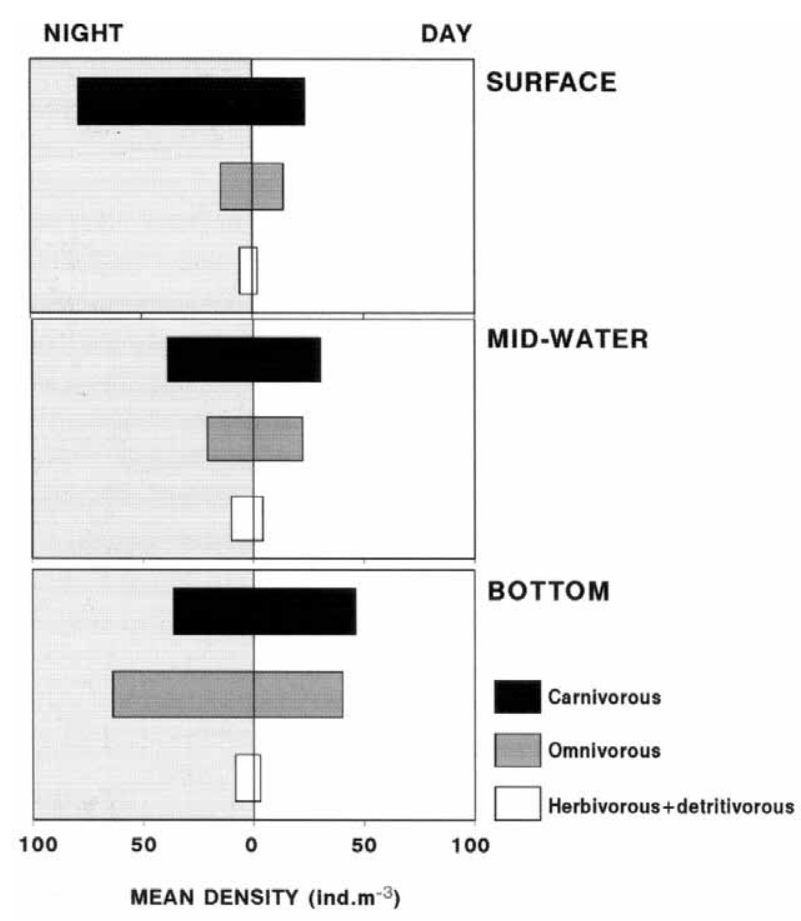

FIG. 5. - Mean density of the zooplankton trophic levels, at the three depths, in the day and night periods. Concentrations (ind. $\mathrm{m}^{-3}$ ) are represented by horizontal bars. Shaded area: night.

icant concentration differences between the phases of the day $(p<0.001)$ and between depths $(\mathrm{p}<0.001)$ (Table 2$)$, with a maximum concentration of 64 ind. $\mathrm{m}^{-3}$ on the bottom at night (representing, in this context $59 \%$ of the total zooplankton). Herbivore and detritivore densities did not show any significant differences, either with the phases of the day or with depths.

When analyzing mean density variations under the influence of the tidal cycle and phases of the day, it is noticeable that all trophic levels were relatively more abundant during floods than during ebbs (Fig. 6). Nevertheless, significant differences were only found for herbivore+detritivore concentrations between tidal phases $(p<0.05)$ and for omnivores between phases of the day $(\mathrm{p}<0.001)$ (Table 2$)$.

The analysis of the influence of the moon and phase of the day on the mean densities of the different trophic levels showed significant differences $(p<0.01)$ with the phase of the moon for all of them (Table 2). Higher densities were attained in new and full moon cycles for carnivores, new moon for the herbivores and first quarter for detritivores (Fig. 7). Omnivores exhibited significant differences $(p<0.001)$ between the phase of the day, and furthermore, a significant interaction between the moon and the phases of the day $(\mathrm{p}<0.01)$ (Table 2).

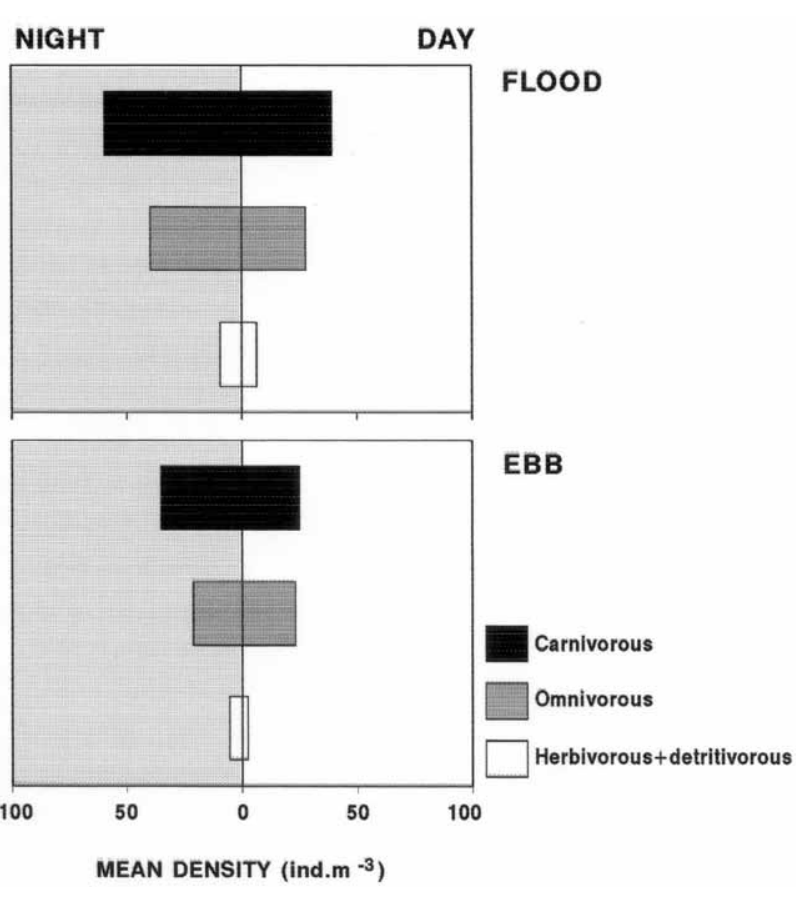

FIG. 6. - Mean density of zooplankton trophic levels, during flood and ebbs, in the day and night periods, at the three depths. Concentrations (ind. $\mathrm{m}^{-3}$ ) are represented by horizontal bars. Shaded area: night.

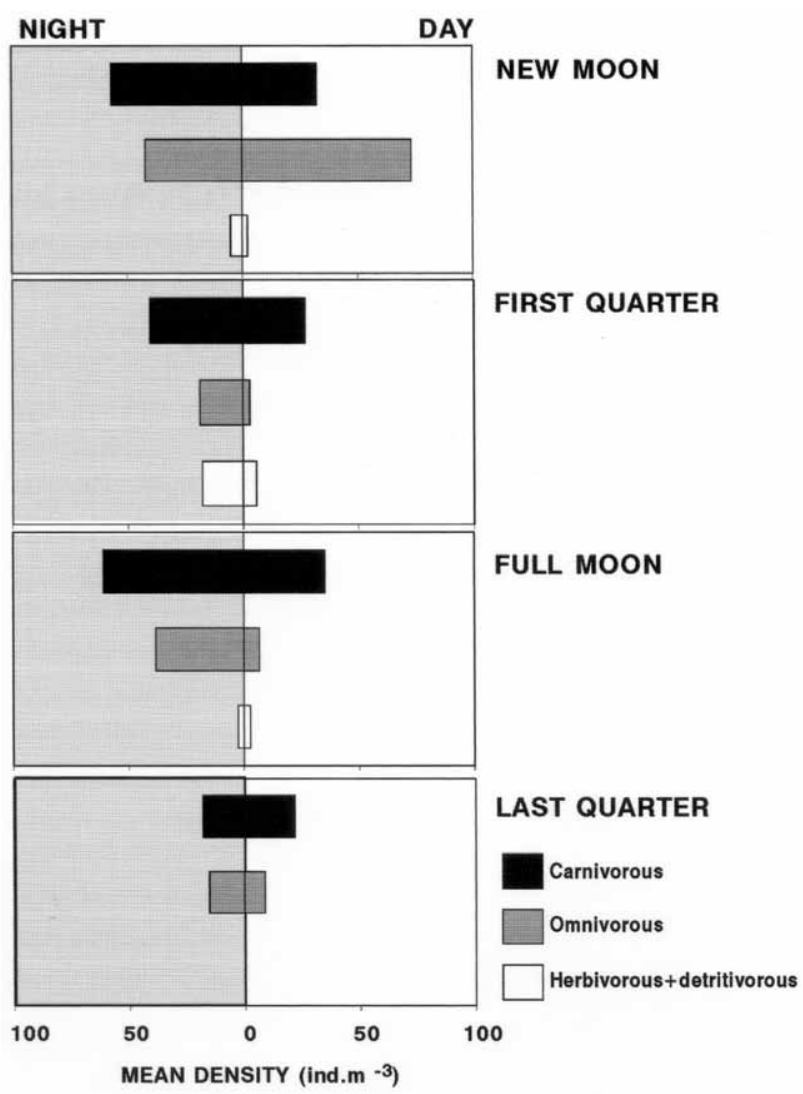

FIG. 7. - Mean density of zooplankton trophic levels, during the phases of the moon, in the day and night periods, at the three depths. Concentrations (ind. $\mathrm{m}^{-3}$ ) are represented by horizontal bars. Shaded area: night. 


\section{DISCUSSION}

The higher zooplankton densities at the surface during the night and at the bottom during the day, with the number of species following a similar pattern, can be highlighted as the conclusion of this study. Many marine and estuarine organisms within a wide range of taxonomic groups of zooplankton are known to display vertical migration in synchrony with the day-night cycle (Schwassmann, 1971; Gajbhiye et al., 1984; Patriti et al., 1984; Stubblefield et al., 1984; Forward, 1988; Bollens and Frost, 1989a,b, 1991; Okemwa, 1989; Hill, 1991a,b,c; De Stasio, 1993). They most commonly show either a nocturnal or twilight pattern. Nocturnal migration is characterized by a movement in which the animals rise to near the surface of the water at night, and attain their maximum depth during the day. Twilight migration is the movement in which the animals descend to their minimum depth near sunset (Forward, 1988). Organisms concentrating near the bottom during the day and migrating towards the surface during the night has been referred to as a way of avoiding predation from visually orientating predators (Zaret and Suffern, 1976; Stubblefield et al., 1984; Bollens and Frost, 1989a,b; Hill, 1995).

Significant differences were observed in the mean number of species between the phase of the day and depth. The higher number of species present at the bottom during floods indicates that a significant number of organisms possess rhythmic behaviour synchronized with tidal cycles. The tidal cycle can be translated into the fluctuations of a variety of environmental variables such as hydrostatic pressure, turbulence and stirring of water, temperature, salinity, and current speed. Among these factors the main inducer of these endogenous rhythms is water turbulence (Enright, 1965). According to Hays (2003) vertical migration may be a means of redistributing populations via vertically stratified horizontal currents. Nevertheless, the observed variation of species number was less dynamic near the bottom when compared with higher levels in the water, where wider variations took place. These observations highlight the migratory behaviour of the organisms within the water column, which can be related to the intensity of the currents, the direction of the tidal current, current velocity and tidal range (Enright, 1970; Decoursey, 1983; Hill, 1991a,b,c; Hill, 1995). Throughout a selective tidal stream transport organisms may experience retention or export mechanisms from the estuarine environment (Jagger, 1999; Pereira et al., 2000). Advection by currents constitutes one of the most significant sources of variability of zooplankton density (Gagnon and Lacroix, 1981; Norcross and Shaw, 1984), which affects all stages of development, eggs and adults, determining different patterns of behaviour in areas submitted to intensive dispersive fluxes (Norcross and Shaw, 1984).

In this work higher zooplankton densities were observed during the new and full moon phases. Some authors argue that differences in zooplankton density associated with the new and full phase of the moon are related to light intensity variations rather than variation in tidal amplitude (Gliwicz, 1986; Jerling and Wooldridge, 1992). Gliwicz (1986) suggests that the moon phase cycle in zooplankton is a global phenomenon induced by predation (demonstrated from an examination of gut contents), as predation on zooplankton occurs most efficiently on nights when the full or nearly full moon rises after sunset, i.e., when zooplankton approach the surface during darkness and become suddenly vulnerable in the first light of the rising moon. After the last quarter, zooplankton density is low, the moon gives little light, predators shift to alternate food sources, and the zooplankton populations grow exponentially again.

The distribution of the various taxa according to trophic level provided relevant information on the nictemeral, tidal and lunar dynamics of the Canal de Mira communities. From a matter transfer point of view we should consider an ascendant flux, which mainly influences the quantity and availability of food sources and conditions primary producer densities, and a descendant flux, which mainly makes an impact on predation and herbivory, with high relevance for the consumers (Hansson et al., 1990; Saint-Jean and Pagano, 1990).

The observed distributions of carnivore and omnivore zooplankters, which suggest nictemeral vertical migrations, can be considered as advantageous regarding competition for food and predatory avoidance. These behavioural patterns highlight important differences in feeding strategies, since carnivores that are dependent on light to identify and detect prey (Zaret and Suffern, 1976; Land, 1992; Lazzaro et al., 1992) come to the surface waters at night, whilst in the same period omnivores can be mainly found in the vicinity of the bottom, hence 
reducing predation and avoiding competition with carnivores. Herbivores and detritivores do not need to see their prey (Lazzaro et al., 1992), hence they are mainly active during the night, which reduces predation by carnivores and omnivores. According to the model developed by Enright (1977) the herbivores can take metabolic advantages with a daily decrease in foraging ability due to depletion of phytoplankton. In the proposed model, herbivorous zooplankton deplete the supply of phytoplankton so much during night time feeding that the metabolic advantage in migrating to lower depths outweighs that of remaining at the surface to feed on a scarce food source. Descent of herbivorous zooplankton may also be a mechanism for sustaining an equilibrium of food supply production (Hansson et al., 1990; Saint-Jean and Pagano, 1990).

The vertical patterns of abundance presented by the dominant species throughout the whole lunar month confirm that, for most species, there were significant interactions between the behaviour strategies and the cyclical variations of the environmental conditions. Species such as Obelia spp., D. ophiogaster, M. atlantica, Diphyes spp., metatrocophores L. conchilega, G. spinifer, S. spiritus and post-larvae $C$. crangon had significantly different densities within the phase of the day. M. atlantica, Diphyes spp., C. helgolandicus, A. clausi, S. spiritus, zoeae $C$. crangon, zoeae $C$. maenas and $O$. dioica registered significantly different densities according to the phase of the tide. Post-veligers H. ulvae, $L$. Littorea eggs, G. spinifer, S. spiritus, zoeae P. elegans, zoeae $C$. crangon, post-larvae $C$. crangon and zoeae $P$. marmoratus showed significant differences of densities with depth. Several interactions were also significant. The densities of $M$. atlantica, Diphyes spp, zoeae $C$. crangon, zoeae $C$. maenas, zoeae P. marmoratus, A. clausi and S. spiritus were significantly affected by the interaction between the phase of the day and the phase of the tide. The densities of G. spinifer, S. spiritus, zoeae de P. elegans, zoeae de $C$. crangon, post-larvae of $C$. crangon and zoeae of $C$. maenas were significantly affected by the interaction between the phase of the day with depth. The densities of $S$. spiritus, zoeae P. elegans, post-larvae de $C$. crangon e zoeae de $C$. maenas were significantly affected by the interaction between the phase of the tide and depth. Densities of G. spinifer, S. spiritus and post-larvae C. crangon were significantly affected by the simultaneous interaction of the three factors. The observed pat- terns for the most abundant species in Canal de Mira (Ria de Aveiro) were in accordance with previous reports from other temperate estuaries concerning gelatinous plankton (Alldredge and Hamner, 1980; Costello and Stancyk, 1983; Esnal et al., 1985), copepoda (Fragoupoulu and Lykakis, 1990; SaintJean and Pagano, 1990), demersal plankton (Williams and Collins, 1984; Orsi, 1986; Mees et al., 1993), as well as fish eggs and larvae of benthic species (Fish, 1979; Barnes, 1981; Christy, 1982; Ré, 1984a,b, 1987; Bachelet and Yacine-Kassab, 1987; Ré, 1990; Paula, 1993; Chase and Thomas, 1995; Queiroga et al., 1997).

For a detailed discussion on the individual species' behaviour inside and in the costal vicinity of the studied system see Morgado et al. (2003a,b).

A marked complexity emerged from the results of this study, concerning the diel and tidal vertical distribution of organisms in the water column, and several patterns may be superimposed in direct accordance with existing environmental factors. They also indicated that the organisms were able to modify their vertical distribution and their diel and tidal rhythms by vertical movements with the tide currents so as to avoid the surface during the daytime and adjust their position inside the water column in order to control the horizontal dislodgement.

\section{REFERENCES}

Alldredge, A.L. and W.M. Hamner. - 1980. Recurring aggregation of zooplankton by a tidal current. Estuar. Coast. Mar. Sci., 10: 31-37.

Bachelet, G. and M. Yacine-Kassab. - 1987. Intégration de la phase post-recrutée dans la dynamique des populations du gastéropode intertidal Hydrobia ulvae (Pennant). J. Exp. Mar. Biol. Ecol., 111: 37-60.

Barnes, R.S.K. - 1994. The Brackish-Water Fauna of Northwestern Europe. An identification guide to brackish-water habitats, ecology and macrofauna for field workers, naturalists and students. Cambridge University Press, Cambridge.

Bollens, S.M. and B.W. Frost. - 1989a. Zooplanktivorous fish and variable diel vertical migration in the marine planktonic copepod Calanus pacificus. Limnol. Oceanogr., 34: 1072-1083.

Bollens, S.M. and B.W. Frost. - 1989b. Predator-induced diel vertical migration in a planktonic copepod. J. Plankton Res., 11 (Suppl. 5): 1047-1065.

Bollens, S.M. and B.W. Frost. - 1991. Diel vertical migration in zooplankton: rapid individual response to predators. $J$. Plankton Res., 13 (Suppl. 6): 1359-1365.

Brookins, K.G. and C.E. Epefanio. - 1985. Abundance of brachyuran larvae in a small coastal inlet over six consecutive tidal cycles. Estuaries, 8 (Suppl. 1): 60-67.

Chase, M.E. and M.L.H. Thomas. - 1995. The effect of the rate and onset of temperature increase on spawning of the periwinkle, Littorina littorea (L.). J. Exp. Mar. Biol. Ecol., 186: 277-287.

Christy, J.H. - 1982. Adaptive significance of semilunar cycles of larval release in fiddler crabs (genus $U c a$ ): test of an hypothesis. Biol. Bull., 163: 251-263.

Costello, J. and S.E. Stancyk. - 1983. Tidal influence upon appen- 
dicularian abundance in North Inlet estuary, South Carolina. $J$. Plankton Res., 5 (Suppl. 2): 263-277.

Decoursey, P.J. - 1983. Biological timing. In: D.E. Bliss (ed.), The Biology of Crustacea, Vol 7. Behaviour and ecology, pp. 107162. Academic Press, New York.

De Stasio Jr., B.T. - 1993. Diel vertical and horizontal migration by zooplankton: populations budgets and the diurnal deficit. Bull. Mar. Sci., 53 (Suppl. 1): 44-64.

Dias J.M., J.F. Lopes and I. Dekeyser. - 2003. A numerical system to study the transport properties in the Ria de Aveiro lagoon. Ocean Dynam., 53: 220-231.

Dodson, S. - 1988. The ecological role of chemical stimuli for the zooplankton: predator-avoidance behaviour in Daphnia. Limnol. Oceanogr., 33: 1431-1439.

Enright, J.T. - 1965. Entrainment of a tidal rhythm. Science, 147: 864-8867.

Enright, J.T. - 1970. Ecological aspects of endogenous rhythmicity. Annu. Rev. Ecol. Syst., 1: 221-238.

Enright, J.T. - 1977. Diurnal vertical migration: adaptive significance and timing. Part I. selective advantage: a metabolic method. Limnol. Oceanogr., 22: 856-872.

Epifanio, C.E. - 1988. Transport of crab larvae between estuaries and the continental shelf. Lecture Notes on Coastal and Estuarine Studies, 22: 291-305.

Esnal, G.B., C. Sankarankutty and R.J. Castro. - 1985. Diurnal and seasonal fluctuations of Oikopleura dioica Fol, 1872 (Tunicata, Appendicularia) in the mouth of the river Potengi (North Brazil). Physis (Buenos Aires), Secc. A, 43 (Suppl. 105): 65-71.

Fenaux, R. - 1967. Les Appendiculaires des mers d'Europe et du Bassin Méditerranéen. Faune de l'Europe et du Bassin Méditerranéen. Masson et Cie., Paris.

Fincham, A.A. - 1977. Larval development of British prawns and shrimps (Crustacea: Decapoda: Natantia). 1. Laboratory methods and a review of Palaemon (Paleander) elegans Rathke, 1837. Bull. Br. Mus. Nat. Hist. (Zool.), 32 (Suppl. 1): 1-28.

Fincham, A.A. and A.J. Figueras. - 1986. Larval keys and diagnoses for the subfamily Palaemoninae (Crustacea Decapoda: Palaemonidae) in the north-east Atlantic and aspects of functional morphology. J. Nat. Hist., 20: 203-224.

Fish, J.D. - 1979. The rhythmic spawning behaviour of Littorina littorea (L.). J. Mollus. Stud., 45: 172-177.

Forward, R.B., Jr. - 1988. Diel vertical migration: zooplankton photobiology and behaviour. Oceanogr. Mar. Biol., 26, 361-393.

Fragopoulu, N. and J.J. Lykakis. - 1990. Vertical distribution and nocturnal migration of zooplankton in relation to the development of the seasonal thermocline in Patraikos Gulf. Mar. Biol., 104: 381-387.

Gagnon, M. and G. Lacroix. - 1981. Zooplankton sample variability in a tidal estuary: an interpretative model. Limnol. Oceanogr., 26 (Suppl. 3): 401-413.

Gajbhiye, S.N., V.R. Nair and B.N. Desai. - 1984. Diurnal variation of zooplankton in Malad Creek, Bombay. Indian J. Mar. Sci., 13: 75-79.

Giske, J., D.L. Aksnes, B.M. Baliño, S. Kaartvedt, U. Lie, J.T. Nordeide, A.G.V. Salvanes, S.M. Wakili and A. AaDnesen. 1990. Vertical distribution and trophic interactions of zooplankton and fish in Masjforden, Norway. Sarsia, 75: 65-81.

Gliwicz, M.Z. - 1986. Predation and the evolution of vertical migration in zooplankton. Nature, 320: 746-748.

Guerney, A.R. - 1982. The larval development of Crangon crangon (Fabricius, 1795) (Crustacea: Decapoda). Bull. Br. Mus. Nat. Hist. (Zool.), 42 (Suppl. 4): 247-262.

Hammer, R.M. - 1981. Day-night influences in the emergence of demersal zooplankton from a sand substrate in a Kelp Forest. Mar. Biol., 62: 275-280.

Hansson, S., U. Larsson and S. Johansson. - 1990. Selective predation by herring and mysids, and zooplankton community structure in a Baltic Sea coastal area. J. Plankton Res., 12 (Suppl. 5): 1059-1116.

Harding, G.C., W.C. Vass, B.T. Hargrave and S. Pearre Jr. - 1986. Vertical movements and feeding activity of zooplankton in St. Georges Bay, N.S., using net tows and a newly developed passive trap. Can. J. Fish. Aquat. Sci., 43: 952-967.

Hays, G.C. - 2003. A review of the adaptive significance and ecosystem consequences of zooplankton diel vertical migrations. Hydrobiologia, 503: 163-170.
Hill, A.E. - 1991a. Advection-diffusion-mortality solutions for investigating pelagic larval dispersal. Mar. Ecol. Prog. Ser., 70: $117-128$.

Hill, A.E. - 1991b. A mechanism for horizontal zooplanktonic transport by vertical migration in tidal currents. Mar. Biol., 111: 485-492.

Hill, A.E. - 1991c. Vertical migration in tidal currents. Mar. Ecol. Progr. Ser., 75: 39-54.

Hill, A.E. - 1995. The kinematical principles governing horizontal transport induced by vertical migration in tidal flows. J. Mar. Biol. Assoc. U.K., 75: 3-13.

Ingle, R.W. - 1987. The first zoea of three Pachygrapsus species and the Cataleptodius floridianus (Gibbes) from Bermuda and Mediterranean (Crustacea: Decapoda: Brachyura). Bull. Br. Mus. Nat. Hist. (Zool), 52: 31-41.

Jagger, Z. - 1999. Selective stream transport of the flounder larvae (Platichthys flesus L.) in the Dolard (Ems Estuary). J. Mar. Biol. Assoc. U.K., 75: 3-13.

Jerling, H.L. and T.H. Wooldridge. - 1992. Lunar influence on distribution of a calanoid copepod in the water column of a shallow temperate estuary. Mar. Biol., 112: 309-312.

Lampert, W. - 1989. The adaptive significance of diel vertical migration of zooplankton. Funct. Ecol., 3: 21-27.

Land, M.F. - 1992. Locomotion and visual behaviour of mid-water crustaceans. J. Mar. Biol. Ass. U.K., 72: 41-60.

Laprise, R. and J.J. Dodson. - 1993. Nature of environmental variability experienced by benthic and pelagic animals in the St. Lawrence Estuary, Canada. Mar. Ecol. Prog. Ser., 94: 129-139.

Lazzaro, X., R.W. Drenner, R.A. Stein and J.D. Smith. - 1992. Planktivores and plankton dynamics: effects of fish biomass and planktivore type. Can. J. Fish. Aquat. Sci., 49: 1466-1473.

Magnesen, T. - 1989. Vertical distribution of size-fractions in the zooplankton community in Lindaspollene, Western Norway. I. Seasonal variations. Sarsia, 74: 59-68.

Magnesen, T., L. Aknes and H.R. Skojoldal. - 1989. Fine-scale vertical structure of a summer zooplankton community in Lindaspollene, Western Norway. Sarsia, 74: 115-126.

Marine Zooplankton Colloquium. - 2001. Future marine zooplankton research-a perspective. Mar. Ecol-Prog. Ser., 222: 297-308.

Mauchline, J. - 1980. The biology of mysids and euphausiids. In: Blaxter, J.H.S., Russell, F. and M. Young. (eds.), Advances in Marine Biology, vol. 18., pp. 681. Academic Press, London, New York, Toronto, Sydney, S. Francisco.

McEwen, G.F., M.W. Johanson and T.R. Folsom. - 1954. A statistical analysis of the performance of the Folsom plankton splitter, based upon test observations. Arch. Meteor. Geophy. Bioklimatol., 7: 502-527.

Mees, J., A. Dewicke and O. Hamerlynck. - 1993. Seasonal composition and spatial distribution of hyperbenthic communities along estuarine gradients in the Westerschelde. Nether. J. Aquat. Ecol., 27 (Suppl. 2-4): 359-376.

Morgado, F.M., R. Melo, H. Queiroga and J.C. Sorbe. - 2003. Zooplankton abundance in a coastal station off the Ria de Aveiro inlet (north-western Portugal): relation with tidal and day/night cycles. Acta Oecol., 24: 175-181.

Morgado, F.M., C. Antunes and M.R. Pastorinho. - 2003. Distribution and patterns of emergence of suprabenthic and pelagic crustaceans from a shallow temperate estuary (Ria de Aveiro, Portugal). Acta Oecol., 24: 205-217.

Neil, W.E. - 1990. Induced vertical migration in copepods as a defense against invertebrate predation. Nature, 345: 524-526.

Neilson, J.D. and R.I. Perry. - 1990. Diel vertical migrations of juvenile fish: an obligate or facultative process?. Adv. Mar. Biol., 26: 115-168.

Neumann, D. - 1981. Tidal and lunar rhythms. In: J. Aschoff (ed.), Biological Rhythms (Handbook of Behavioral Neurobiology), vol. 4, pp. 351-380. Plenum Press, New York.

Norcross, B.L. and R.F. Shaw. - 1984. Oceanic and estuarine transport of fish eggs and larvae. A review. T. Am. Fish. Soc., 113: 153-165.

Okemwa, E. - 1989. Analysis of six 24-hour series of zooplankton samplings across a tropical creek, the Port Reitz, Mombasa, Kenya. Trop. Zool., 2: 123-138.

Orsi, J.J. - 1986. Interactions between diel vertical migration of a mysidacean shrimp and two-layered estuarine flow. Hydrobiologia, 137: 79-87.

Paffenhoper, G.A. - 1983. Vertical zooplankton distribution on the 
northeastern Florida shelf and its relation to temperaure and food abundance. J. Plankton Res., 5 (Suppl. 1): 15-33.

Patriti, G., G. Champalbert and R. Arfi. - 1984. Eulerian sampling of zooplankton from Marseilles' Vieux Port over a $24 \mathrm{~h}$ period. Mar. Biol., 82: 135-142.

Paula, J. - 1993. Ecologia da Fase Larvar e Recrutamento de Crustáceos Decápodes no Estuário do Rio Mira. Ph. D. thesis, Faculdade de Ciências da Universidade de Lisboa, Lisboa.

Pereira, F., R. Pereira and H. Queiroga. -2000. Flux of decapod and juvenils at a station in the lower Canal de Mira (Ria de Aveiro, Portugal) during a lunar month. Invertebr. Reprod. Dev., 38 (Suppl. 3): 183-206.

Queiroga, H. - 1995. Processos de Dispersão e Recrutamento das larvas do Caranguejo Carcinus maenas (L.) na Ria de Aveiro. $\mathrm{Ph}$. D. thesis, Departamento de Biologia da Universidade de Aveiro, Aveiro.

Queiroga, H., J.D. Cstlow Jr. and M.H. Moreira. - 1997. Vertical migration of the crab Carcinus maenas first zoea in an estuary: implications for tidal stream transport, Mar. Ecol. Prog. Ser., 149: 121-132.

Ré, P. - 1984a. Ictioplâncton da região central da costa Portuguesa e do estuário do Tejo. Ecologia da postura e da fase planctónica de Sardina pilchardus (Walbaum, 1792) e de Engraulis encrasicolus (Linné, 1758). Ph. D. thesis, Universidade de Lisboa, Lisboa.

Ré, P. - 1984b. Evidence of daily and hourly growth in pilchard larvae based on otolith growth increments, Sardina pilchardus (Walbaum, 1792). Cybium, 8 (Suppl.1): 33-38.

Ré, P. - 1987. Ecology of the planktonic phase of the anchovy, Engraulis encrasicolus (L.), within Mira estuary (Portugal). Inv. Pesq., 51 (Suppl. 4): 581-598.

Ré, P. - 1990. Tidal transport and retention of anchovy eggs and larvae within Mira estuary (Portugal). Portugaliae Zoologica, 1 (Suppl. 2): 7-13.

Rice, A.L. and R.W. Ingle. - 1975a. The larval development of Carcinus maenas (L.) and C. mediterraneus Czerniavsky (Crustacea, Brachyura, Portunidae) reared in the laboratory. Bull. Br. Mus. Nat. Hist. (Zool.), 28 (Suppl. 3): 101-119.

Rice, A.L. and R.W. Ingle. -1975 b. A comparative study of the larval morphology of the British portunid crabs Macropipus puber (L.) and M. holsatus (Fabricius), with a discussion of generic and sub-familial larval characters within the Portunidae. Bull. Br. Mus. Nat. Hist. (Zool.), 28 (Suppl. 4): 121-151.

Rose, M. - 1933. Faune de France. Copépodes pélagiques. Ed. Fédération Française des Societés de Sciences Naturelles, Paris.

Russell, F.S. - 1953. The Medusae of the British Isles. Cambridge University Press, London.

Saigusa, M. - 1985. Tidal timing of larval release activity in nontidal environment. Jpn. J. Ecol., 35: 243-251.
Saigusa, M. and T. Akiyama. - 1995. The tidal rhythm of emergence, and the seasonal variation of this synchrony, in an intertidal midge. Biol. Bull., 188: 166-178.

Saint-Jean, L. and M. Pagano. - 1990. Variation nycthémerale de la répartition verticale et de l'efficacité de collecte du zooplancton en lagune Ebrié (Côte d'Ivoire). Hydrobiologia, 194: 247-265.

Schwassmann, H.O. - 1971. Biological rhythms. In: Fish Physiology, vol. 6, Academic Press (ed.), pp. 371-427.

Sekino, T. and N. Yamamura. - 1999. Diel vertical migration of zooplankton: optimum migrating schedule based on energy accumulation. Evol. Ecol., 13: 267-282.

Sekino, T. and T. Yoshioka. - 1995. The relationship between nutritional condition and diel vertical migration of Daphnia galeata. Jpn. J. Limnol., 56: 145-150.

Simard, Y., G. Lacroix and L. Legendre. - 1986. Diel migrations and nocturnal feeding of a dense coastal krill scattering layer (Thysanoessa raschi and Meganyctiphanes norvegica) in stratified surface waters. Mar. Biol., 91: 93-105.

Stuart, V. and H.M. Verheye. - 1991. Diel migration and feeding patterns of the chaetognath Sagitta friderici, off the west coast of South Africa. J. Mar. Res., 49: 493-515.

Stubblefield, C.L., C.M. Lascara and M. Vecchione. - 1984 Vertical distribution of zooplankton in a shallow turbid estuary. Contrib. Mar. Sci., 27: 93-104.

Totton, A.K. and H.E. Bargmann. - 1965. A Synopsis of the Syphonophora. Trustees of the British Museum of Natural History, London.

Trégouboff, G. and M. Rose. - 1957. Manuel de Planctonologie Méditerranéenne. Centre National de la Recherche Scientifique, $1^{\text {st }}$ ed., Paris.

Williams, A.B. and N.R. Collins. - 1984. Distribution and variability in abundance of Schistomysis spiritus (Crustacea: Mysidacea) in the Bristol Channel in relation to environmental variables, with comments on other mysids. Mar. Biol., 80: 197-206.

Wooldridge, T. and T. Erasmus. - 1980. Utilization of tidal currents by estuarine zooplankton. Estuar. Coast. Shelf Sci., 2: 107-114.

Yamaguchi, A., T. Ikeda, Y. Watanabe and J. Ishizaka. -2004. Vertical Distribution Patterns of Pelagic Copepods as Viewed from the Predation Pressure Hypothesis. Zool. Stud., 43 (Suppl. 2): 475-485.

Zaret, T.M. and J.S. Suffern. - 1976. Vertical migration in zooplankton as a predator avoidance mechanism. Limnol. Oceanogr., 21 (Suppl. 6): 804-813.

Zar, J.H. - 1984. Biostatistical Analysis. Prentice-Hall, Inc., New Jersey.

Scient. ed.: M. Alcaraz

Received April 15, 2005. Accepted December 16, 2005. 